\title{
Study of the Effect of Crop Patterns on Farm Water Losses at North and West Nile Delta, Egypt
}

\author{
Saied M.M; Ragab,M.M.; Omar,E.H. and Abd Elaziz,M.A. ${ }^{1}$
}

\begin{abstract}
Egypt is considered as semi arid region, therefore, water is the limiting resource to maximize the agricultural production. To maximize the benefit of water resource, it is necessary to identify the causes of irrigation water losses through the system of irrigation on the farm level and water budget studies were conducted during summer season, 2005 on four branch canals. Dakalt and El Kahawagy branch canals represented Kafr El Shiekh Governorate (North Nile Delta), while Besntway and El Hamamy branch canals represented, El Behera Governorate (West Nile Delta). Two improved mesqas were selected at Kafr El Shiekh, and four at El Behera, were selected at different locations. The cropped areas for the selected mesqas in Kafr El Sheikh Governorate ranged from 71.43 to $100 \%$ for rice, 0.0 to $28.34 \%$ for cotton and 0.00 to $0.23 \%$ for maize. While in El Behera governorate, the cropped area ranged from 11.83 to $\mathbf{7 5 . 6 1 \%}$ for rice, 4.59 to $58.93 \%$ for cotton, 0.96 to $3.76 \%$ for maize, 1.03 to $36.09 \%$ for fruits and 0.54 to $4.88 \%$ for vegetables. The conveyance efficiency average values ranged from 78.64 to $83.56 \%$ for Kafr El Sheikh and from 78.12 to 86.57 \% for El Behera. Water conveyance losses in earth marwas were found to be $18.9 \%$ and $16.76 \%$ for Kafr EI Shiekh and El Behera, respectively.
\end{abstract}

Field irrigation efficiency was a minimum value for $\mathrm{El}$ Naira mesqa $(55.81 \%)$ because all area cultivated with rice, but it was $80.26 \%$ in Sharf El Den mesqa when rice occupied $35.73 \%$ of the total area.Total benefit values could be arranged as following ascending order: El Shemy \& El Taweel mesqa > Ganab 1 mesqa > Sharaf El Den mesqa > Om Henesh C mesqa >El Deeb \& Abd Ella mesqa $>\mathrm{El}$ - Naira mesqa. The most efficient utilization of water unit was achieved when rice area ranged between 11.8 and $66 \%$ of the total mesqa area to maximize the return of water unit and minimize water conveyance and field losses. The crop pattern should be adopted with mesqa water supply to ensure higher on - farm irrigation efficiency and reduce water losses.

Key words: Cropping pattern on farm water losses , and efficiencies.

\section{INTRODUCTION}

In the arid and semi arid areas of the world, the limiting resource to maximize agricultural production is water. The River Nile is the main water sources. In Egypt, $85 \%$ of the available water supply (55.5 billion cubic meters annually) is consumed by the agriculture sector. The water conservation and maximize water use efficiency is a crucial issue that represents the keystone for agriculture extension. . To maximize the benefit of this resource, it is necessary to recognize and identify where water loss are occurring, its magnitude and how control it. Water budget is a tool can used to solve this problem.

Ley et al (1984) indicated that $40 \%$ of water might be lost from unimproved filed ditches. Water conservation could be fulfilled through better management where water balance studies on different levels are the main foundation for the conservation process. The average overall irrigation efficiency in Nile Delta is about 50\%. Most of water losses occur in mesqas, marwa and in field (Shawky and El - Kashef, 2004).

The main aspect of water resources system is the economic usage of water. About 50 percent of the total water available for irrigation in India is diverted to rice crop alone with the assumption that the water requirement of rice is very high, without any basis for the assumption. Out of this 50 percent water is consumed by rice; $60-70$ percent quantity is lost by deep percolation and evaporation (Kumar Raj et al 1999).

In Egypt, a large percentage of agricultural land is suffering from water logging and salinity problems (Up to $33 \%$ of the delta affected). Also, farmers complain of shortage in specific locations along canals, or at particular times within the irrigation cycles (Metawi, 1989). This is a result of the inefficient of water at the local level. Therefore, the objectives of this study are aimed to estimate the existing water losses on earth marwa under different actual cropping patterns and the suitable cropping pattern to minimize water losses and maximize crop return per unit of water.

\section{MATERIALS AND METHODS}

Water balance studies were conducted during summer season of 2005 in two locations i.e.; one location in Kafr El Sheikh governorate, which include two sites. The first site is located at Dakalt branch canal (Om Henesh C, mesqa) with cropping pattern $71.43 \%$ rice and $28.34 \%$ cotton of total area. The 2 nd site is located at El Kahwagy branch canal (El Naira mesqa) at which the rice crop occupied all area (100\%).

\footnotetext{
${ }^{1}$ Soil Water Environment Research Institute, ARC, Egypt

Received November 22, 2007, Accepted December26, 2007
} 
Another location was at El Behera Governorate and included four sites: two sites at Besentway branch canal i.e.; Sharf El Den and El Deeb \& Abd Ella mesqas, (35\% rice, $65 \%$ cotton) and (75\% rice, $25 \%$ cotton), respectively. And two sites at El Hamamy branch canal; Ganab, 65\% rice, $25 \%$ fruit and $10 \%$ maize and $\mathrm{El}$ Sheemy \& El Taweel 12\% rice , $48 \%$ cotton , 36\% fruit and $4.0 \%$ maize.

The metrological data for Kafr El Sheilh and El Behera Governorates were recorded. The average maximum temperature for summer months were $34{ }^{\circ} \mathrm{C}$ in July and $32.8{ }^{\circ} \mathrm{C}$ in August, respectively at Kafr El Shiekh and El Behera. While, the minimum temperature were 10.3 and $12.3{ }^{\circ} \mathrm{C}$ in April, respectively at Kafr El Shiekh and El Behera. The relative humidity varied from 59 to $75 \%$ in Kafr El Shiekh and from 54 to $65 \%$ in El Behera. The average wind speed was $1.3 \mathrm{Km} / \mathrm{h}$ in both locations .The average of solar radiation were $518.5580 .9 \mathrm{Cal} . / \mathrm{cm}^{2} / \mathrm{min}$. and average values of evapotranspiration were 6.03 and $5.45 \mathrm{~mm} /$ day, respectively at Kafr El Shiekh and El Behera..

In each site, the crop pattern was surveyed, the amount of water applied for each crop was measured within an area served by a distributary canal (mesqa) and their private canals( marwas) which deliver water to farmers fields.

\section{The measurements and calculations:}

1-Water conveyance efficiency: It was calculated in the selected earth marwas as the ratio of discharge at the second cutthroat flume (application point at $100 \mathrm{~m}$ distance from the first cutthroat flume) to the flow rate at the $1^{\text {st }}$ flume ( lifting point).

\section{Flow at flume (2)}

Conveyance efficiency $=$

Flow at flume (1)

2-Irrigation water losses: It consists of seepage from the earth canal into the underlying groundwater and spills, which occur from leaky banks, overtopping the banks of the canals. A method of reporting the loss is the percent loss and expressed as follow:

Losses $=1$ - Conveyance efficiency

3-Amount of irrigation water applied: Amount of irrigation water applied was measured for different summer crops by using a cutthroat flume $(20$ x 90 $\mathrm{cm})$ according to early, (1975).

4-Water utilization efficiency: It was calculated by dividing crop yield $(\mathrm{kg})$ on applied water $\left(\mathrm{m}^{3}\right)$

5-Crop eavapotranspiration: Crop eavapotranspiration for different summer crops was calculated using Penman Monteith equation and crop coefficient
(FAO Irrigation and Driange Technical Paper No. 56).

6-Water losses at on- farm level: The general equation of continuity for a fluid dynamic (Daily and Harleman, 1966; Daugherty and Franzini, 1977).

7-Hydrologic studies: For hydrologic studies a simplified form of the equation for a fixed control volume and a specific period of time may be used: $\mathrm{I}_{\mathrm{T}}-\mathrm{D}_{\mathrm{T}}=\Delta \mathrm{ST}$

Where,

$I_{T}=$ Total inflow volume of water into the control volume during time period $\mathrm{T},\left(\mathrm{m}^{3}\right)$

$D_{T}=$ Total outflow volume of water during time period $\mathrm{T},\left(\mathrm{m}^{3}\right)$

$\Delta S T=$ Total change in volume of water during time period $\mathrm{T},\left(\mathrm{m}^{3}\right)$

8-On farm irrigation efficiency obtained by divide water consumptive use on the amount of water applied.

9-The field water losses equal 100 - on farm irrigation efficiency.

10- Total crop return: It is equal to water utilize efficiency $\mathrm{x} \%$ of crop area of the selected mesqa $\mathrm{x}$ average of unit price. The total benefits were obtained by summation of crop return on mesqa and it depends on the kind of crops and relative area of which crop cultivated.

\section{RESULTS AND DISCUSSION}

\section{A.Crop patterns:}

The crop patterns for the selected mesqas are given in Table 1. Data show that the relative rice areas ranged between 11.83 and 100\% for El Sheemy \& El Taweel and El Naira mesqas, respectively of the Total area served by these mesqas. Cotton crop occupied the secondorder which recorded the ratios varied from 4.59 to $58.93 \%$ for Ganab and sharf El Den mesqas, respectively. In this respect, the third order was fruits which represent 1.8 to $36.09 \%$ for Sharaf El Den and El Sheemy \& El Taweel mesqas, respectively. Also, maize and tomato crops occupied small areas.

\section{B.Conveyance losses in earth marwas:}

On- farm water delivery is accomplished through a system of marwas. These marwas are difficult to be maintained in good conditions due to the cracks, this cracks cause direct seepage of irrigation water through it, change the cross sections, and prevents successful compacting of marwa banks.

Significant On-Farm conveyance losses have been observed between outlet of valves and point of application along marwas, these water losses might be due to leakage and dead storage. 
Table 1. Crop patterns in summer, 2005 for selected mesqas located at Kafr EI - Sheikh and EI - Behera Governorates

\begin{tabular}{|c|c|c|c|c|c|c|}
\hline Branch Canal & Selected mesqas & $\begin{array}{c}\text { Rice } \\
\% \\
\end{array}$ & Cotton \% & $\begin{array}{c}\text { Maize } \\
\% \\
\end{array}$ & $\begin{array}{c}\text { Fruits } \\
\% \\
\end{array}$ & Tomato\% \\
\hline \multicolumn{7}{|c|}{ Kafr El- Shiekh } \\
\hline Dakalt & Om Henesh C & 71.43 & 28.34 & 0.23 & & \\
\hline El - Kahwagy & El - Naira & 100 & - & - & & \\
\hline \multicolumn{7}{|c|}{ El-Behera } \\
\hline \multirow[t]{2}{*}{ Besntway } & Sharf El -Den & 35.73 & 58.93 & 3.76 & 1.03 & 0.54 \\
\hline & El Deeb \& Adb Ella & 75.61 & 19.51 & - & - & 4.88 \\
\hline \multirow[t]{2}{*}{ El - Hamamy } & Ganab 1 & 66.78 & 4.59 & 0.96 & 23.18 & 4.49 \\
\hline & El -Sheemy \& El -Taweel & 11.83 & 48.61 & 3.49 & 36.09 & - \\
\hline
\end{tabular}

.Data in Table2. show the conveyance losses of earth marwas that located on selected mesqas in the studied area.

The obtained results revealed that the mean values of conveyance losses across different locations are ranged from $13.43 \%$ to $21.88 \%$ at sharaf El Den mesqa and El Sheemy \& El Taweel mesqas. The conveyance efficiencies were 78.64 and $83.56 \%$ for Om Heneesh (C) and El-Naira mesqas at kafr El - Sheikh, respectively. While the $2^{\text {nd }}$ location at El-Behera Governorate the conveyance efficiencies were 86.57, 84.69, 83.57 and $78.12 \%$, for Sharf El Den,ElDeb\&Abd Ella Ganab1 and El Shemy\&El Taweel mesqas, respectively.It is important to mention to that the greater conveyance losses the greater the areas of rice crop The water losses ranged from 13.43 to $21.88 \%$ under different conditions. The obtained results are in agreement with those obtained by Ley et al. (1984) and Shawky and El-Kashef (2004). Also, data indicated that the mean values of conveyance efficiency were 81.07 and $84.53 \%$ for Dakalt and El - Kahwagy branch canals respectively in Kafr El Shiekh governorate. While the corresponding values were 85.11 and $81.3 \%$ for Bsentway and El - Hamamy branch canals respectively in El Behera governorate. These results are in agreement with those reported by Shawky and El Kashef, (2004).

\section{On Farm water losses and irrigation efficiency:}

Applied water, crop water consumptive use, water losses and on - farm irrigation efficiency for the selected mesqas are presented in Table3.

The results indicate that rice crop recorded the highest values of on - farm water losses and lowest on farm irrigation efficiency in different selected locations It's clear that rice crop recorded the highest value of on farm water losses which ranged from $40.98 \%$ in Sharaf El Den for Bsentway branch canal to $45.83 \%$ in Om Henesh ( C) for Dakalt branch canal. Data also showed that the percentage of on - farm water losses increased by increasing the area occupied by rice crop.. Results revealed that the mean values of farm water losses varied in wide range from $12.85 \%$ in cotton crop at $\mathrm{El}$ Deeb \& Abd Ella mesqa to $21.57 \%$ at Sharaf El Den mesqa. Cotton crop area ranged from 4.59 to $58.93 \%$ of the total area of Ganab, and Sharaf El Den, respectively. Minimum efficiency was $(55.81 \%)$ when all area cultivated with rice in El Naira mesqa, but reached to $80.26 \%$ when rice occupied $35.73 \%$ of the total area in Sharaf El Den mesqa.

Table 2. On-farm marwa conveyance efficiency and their losses during individual irrigations on some mesqas located in Kafr El-Sheikh and El-Behera Governorate

\begin{tabular}{ccccc}
\hline Governorate & Branch Canal & Mesqa Name & $\begin{array}{c}\text { Conveyance } \\
\text { Efficiency, \% }\end{array}$ & $\begin{array}{c}\text { Conveyance } \\
\text { Losses } \\
\text { \% }\end{array}$ \\
\hline \multirow{2}{*}{ Kafr El - Shiekh } & Dakalt & Om Heneesh (C) & 78.64 & 21.36 \\
& El-Kahwagy & El-Naira & 83.56 & 16.44 \\
& Bsentway & Sharaf El-Den & 86.57 & 13.43 \\
& & El-Deb \& Abd Ella & 84.69 & 15.31 \\
El-Behera & Ganab 1 & 83.57 & 16.43 \\
& El-Hamamy & El-Sheemy \& El- & 78.12 & 21.88 \\
& & Taweel & \\
\hline
\end{tabular}


Table 3.Water losses and on farm irrigation efficiency for selected mesqas located at Kafr EI Sheikh and El-Behera Governorate during summer season 2005

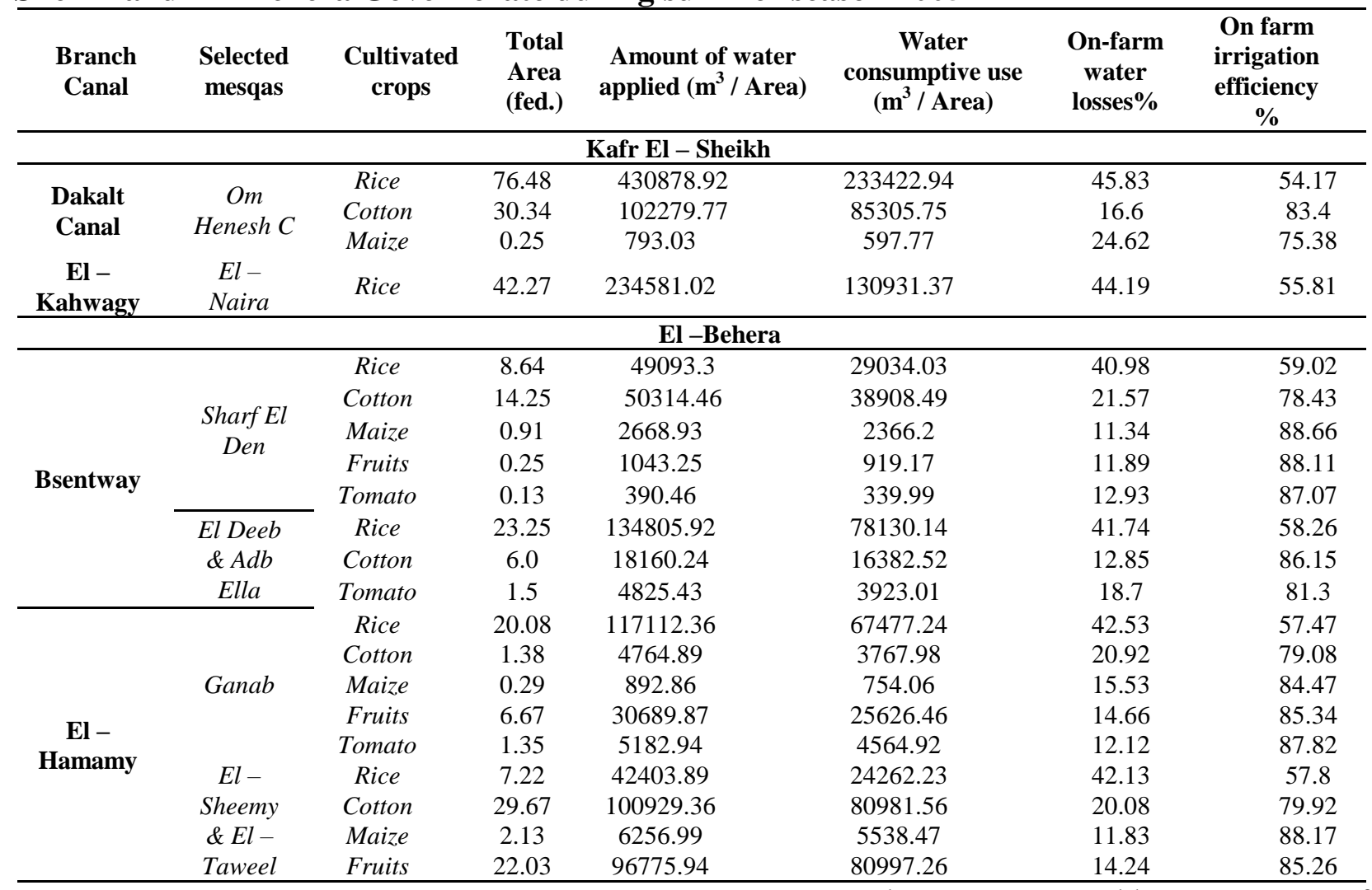

Therefore, the optimum state was recorded by $35 \%$ rice as in Sharaf El Denmesqa. Maize crop occupied small areas different from $0.23 \%$ to $3.76 \%$ with water losses ranged between $11.34 \%$ to $24.62 \%$, respectively with mean value of $15.8 \%$ under different studied locations. This may be due to the opportunity of water evaporation and deep percolation. D. Water utilization efficiency and total relative benefits.

Data of water utilization efficiency are presented in Table 4.

It is clear that tomato crop recorded the highest values water unit productivity, follow by fruits crops. While the cotton crop recorded the lowest values of water unit productivity.

It could be ranking the different cropping patterns according to their total benefit values as follows: El Shemy \& El Taweel mesqa > Ganab 1 mesqa at El Hamamy branch canal $>$ Sharf El - Den mesqa $>$ Om Henesh C mesqa >El Deeb \& Abd Ella mesqa >El Naira mesqa. On the other hand, El Naira mesqa takes the last ranking when all area cultivated with rice crop.

\section{Conclusion}

It is necessary to make arrangement between the farmers, ministry of agricultural and ministry of water resources to plan crop pattern and best management of water resources. It could be concluded that the best utilization benefit of water unit was achieved when rice area ranged between 11.8 and $66 \%$ of the total mesqa area to maximize the return of water unit and minimize water conveyance and field losses.

\section{RE FERENCES}

Daily, J.W. and D.R.F Harleman. (1966). Fluid Dynamics. Addison - Wesley publishing company, Reading, Mass.

Daugherty, R.L. and J.B. Franzini. (1977). Fluid Mechanics with engineering applications. ( ${ }^{\text {th }}$ Ed.). Mc Graw - Hill Book company, New York.

Early, A.C. (1975). Irrigation scheduling for wheat in Punjab. CENTO scientific programme on the optimum use of water in agriculture. Report No. 17, LyAllpur, Pakistan, 3-5 March, pp 115-127.

El Zawahry, A. and N. Zaki (1989). "Mathematical Modelling of water balance," case study: Dikernis pilot area.

kumar Raj, R.; N.V. pundarikanthan and K.R. Chezain (1999). Controlled water saving method for paddy cultivation. A case study published in Transactions, 
$17^{\text {th }}$ international Congress on irrigation and Drainage

volume I A - Question 48, Granada, Spain, (1999).

Ley, T.W; Mona El Kady; K. Litwiller; E.E. Hanson; W. Branuworth; S; Assia El Flaky and E. Wafik (1984). The influence of farm irrigation system design and precision land levelling on irrigation efficiency and irrigation water management.

EWUP technical report No. 41, May, (1984).

Metawie, A.F. and J.F. Ruff (1987). Asian Regional Conference, Cairo, Egypt, B 10, (1987).

Metawie, A.F. (1989). Feasibility of local off - stream storage ponds to reduce discrepancies between supply and demand, Unpubl. Ph. D Thesis, Colorado State Univ.
Mohamed, H.; A. Naser; M. Ibrahim; K.G. Timothy; O.R. William and M.Semaika (1980). "Water budget for irrigation regions in Egypt" EWUP technical report No. 47, Cairo Egypt, and Ft Collins, Colorado, USA, (1980).

Pearce, G.R. (1987). "Analysis of water management practice on small scale irrigation scheme in Africa for improved design techniques - Studies in Eastern Zimbabwe", Six Afro Asian Regional Conference, Cairo, B 8, (1987).

Rady, M.A. and W. Fahim (1987) "Remarks on the application of water management practices in Egypt. Six Afro Asian Regional Conference, Cairo, B 9, (1987).

Rihard, G.A.; Luiss Pereira; Dirk Raes and Martin. Smith (1998). Crop evapotranspiration. Guidelines for computing crop water requirements. FAO Irrigation and Drainage paper No.65.

Shawky,M.E. and A.El-Kashef (2004). On farm water management component IIIMP per appraisal Mission, December 2004. 


\section{الملخص العربي}

\section{دراسة اثر التركيب المحصولى على الفواقد المائية على مستوى الحقل فى شمال و غرب دلتا النيل}

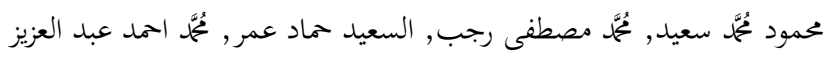

كانت نسبة فقد المياه في المراوي الترابية لكل من محافظتي كفر

$$
\text { الشيخ والبحيرة هي } 18.9 \text { و } 16.76 \text { \% على الترتيب. }
$$

وصـلت القيمـة المتوسطة لكفــاءة الري على مستوى الحقـل إلى

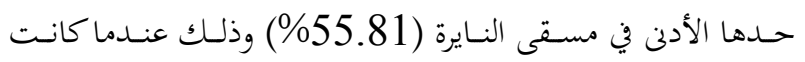

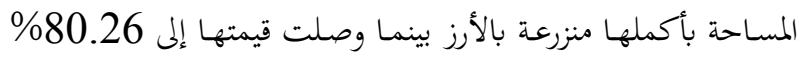

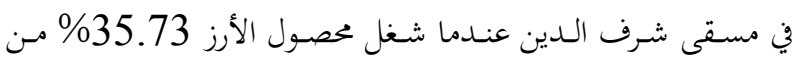

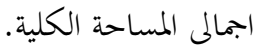

ازدادت قيمـة الفواقــــ المائيـة بينمـا قلـت قيمـة كفـاءة الري على

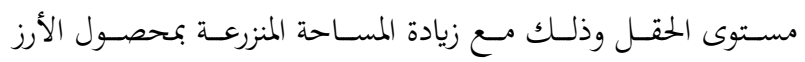
والعكس.

يمكن ترتيب العائد الكلى من المساقى المختارة تصاعديا كما يلي:

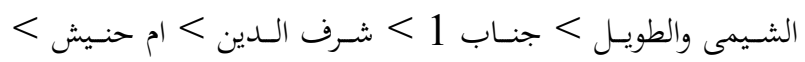

$$
\text { الديب وعبد اللاه > النايرة . }
$$

$$
\text { > الديب وعبد اللاه > النايرة . }
$$

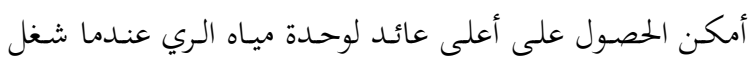

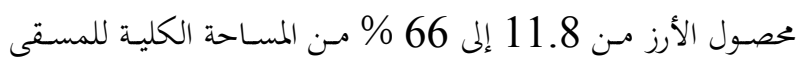
وذلك نتيجة لتقليل نسبة الفواقد على مستوى الحقل. وبذلك يمكن التوصية انه لابـد من التنسيق بين كل مـن اجهزة

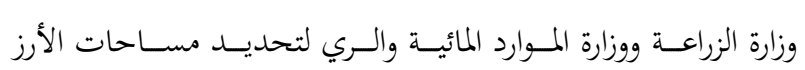

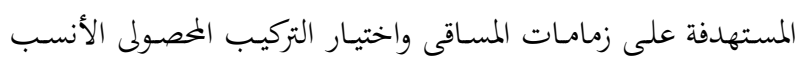

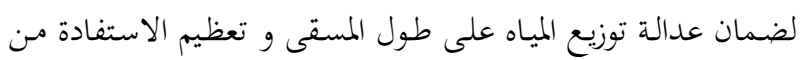

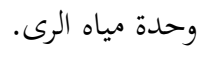

تقع مصر في حزام المنـاطق شبه الجلافة للذلك تعد المياه العامل

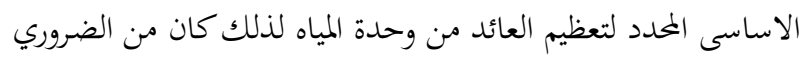
تقدير الفواقد المائية على مستوى الحقل. تم دراسة الميزان المائي في الموسم الصيفي لعام 2005على مستوى أربعة ترع فرعية حيث تم اختيار ترعتي دقلت و القهوجي ليمثلا محافظة كفر الشيخ (شنمال الدلتا) و كذلك اختيار ترعتي بسنتواى و الحمامى رئي

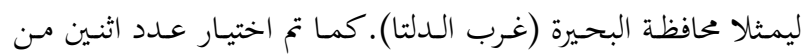

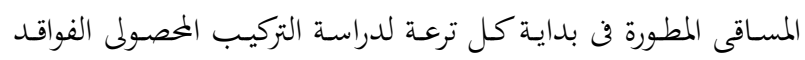
المائية وكفاءة الري على مستوى الحقل. ويمكن تلخيص أهم النتائج المتحصل عليها فيما يلي:

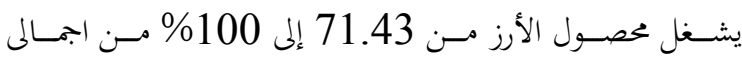
المساحة المنزرعة من زمام المساقى المختارة في محافظة كفر الشيخ بينما

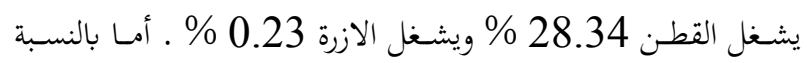

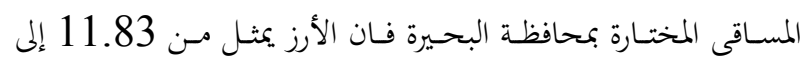
75.61 \% مـ اجمالى المساحة المنزرعة والقطن يشغل مـن 4.59 إلى 58.93 بينما يشغل الازرة والفاكهة من 0.96 إلى 3.76 \% 363 \%

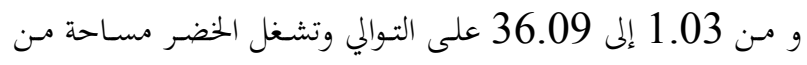
0.54 إلى 4.88\% من المساحة الكلية على المسقى. تراوحت كفـاءة نقل المياه في المراوي الترابية في المساقى المختـارة

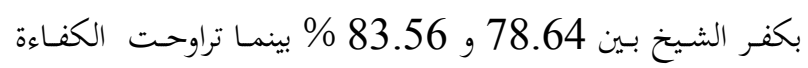
بين 78.12 و 86.57 \% بمحافظة البحيرة. 